УДК: 32.019.52

УСМАНОВА Заира Романовна - кандидат политических наук, доцент департамента политологии факультета социальных наук и массовых коммуникаций Финансового университета при Правительстве РФ (125993, Россия, г. Москва, ГСП-3, Ленинградский пр-кт, 49; ZRUsmanova@ fa.ru)

\title{
ОБРАЗЫ ИДЕАЛЬНЫХ ПАРЛАМЕНТА И ПОЛИТИЧЕСКОЙ ПАРТИИ В СОЗНАНИИ РОССИЙСКИХ ГРАЖДАН: РЕЗУЛЬТАТЫ ПОЛИТИКО- ПСИХОЛОГИЧЕСКОГО ИССЛЕДОВАНИЯ
}

\begin{abstract}
Аннотация. В статье представлены результаты исследования идеальных образов парламента и политической партии. На основе политико-психологического подхода были получены следующие результаты. Парламент в сознании респондентов представлен суммой формальных символов, образ характеризуется когнитивной простотой. Автор выявляет высокую степень эмоциональной окрашенности образа, которая отражает в большей мере личные переживания респондентов, их желание улучшить свое социально-экономическое положение, чем моделировать возможные преобразования в политической сфере в условиях неопределенности. Граждане имеют размытое представление о партийной деятельности, разграничивают образы идеальной и действующих партий, выделяют в числе наиболее узнаваемых парламентские партии.
\end{abstract}

Ключевые слова: идеальный парламент, идеальная партия, Государственная дума, Совет Федерации, депутат, доверие власти, образ будущего

Исследование выполнено при финансовой поддержке РФФИ и ЭИСИ в рамках научного проекта № 20-011-31369 «Образ идеального будущего: нормативные представления российских граждан о власти, политических институтах и лидерах».

Актуальность и научная дискуссия. Исследование политических образов, формирующихся в массовом сознании, имеет большой интерес для научного сообщества, особенно в периоды социально-политических трансформаций. В условиях кризисов, когда еще не успели выработаться конвенциональные смысловые ориентиры, граждане могут испытывать фрустрацию, стрессы и тревоге, что отражается на формировании новых представлений, которые могут быть размытыми. В то же время для того, чтобы принимать меры для коррекции информационной политической повестки, необходимо понимать, какой «идейный пазл» складывается в массовом политическом сознании сегодня. В данном контексте важной представляется проблематика изучения нормативных образов политических субъектов и институтов с точки зрения поиска ответов на следующие вопросы: каковы характеристики идеальных политических объектов в сознании российских граждан и насколько они близки к реальным? существуют ли противоречия между этими образами и как оценивается гражданами возможность достижения «идеального будущего»? можно ли в настоящее время говорить о завершении трансформационного политико-культурного процесса в стране, и выработаны ли в массовом сознании однозначные смысловые конструкции, описывающие политическую повседневность? влекут ли новые вызовы макрополитического масштаба преобразования в картине 
мира российских граждан? Ответы на эти и другие исследовательские вопросы помогут лучше понять роль идеальных образов в восприятии политических событий, мотивы участия граждан в общественно-значимых политических проектах, социально-психологические основания мобилизации их активности (или пассивности) в сфере политики.

Изучению особенностей политической перцепции посвящены труды многих ученых-гуманитариев. В частности, следует обратить внимание на работы, посвященные определению специфики восприятия парламента, его палат, института парламентаризма в целом [Габдрахманова 2014; Моисеева 2018; Щербинин 2019; Воропаева 2020]. Исследования, посвященные рассмотрению отдельных когнитивных, аффективных и поведенческих аспектов парламентской культуры, расширили исследуемое поле и также использовались в качестве научного задела в данной работе [Кирдяшкин 2020]. Значительное число трудов посвящено трактовке парламентаризма как перцептивного условия формирования нормативных представлений о парламентских политических партиях и складывания политических представлений об электоральном процессе. Здесь для нас представляют интерес как иностранные работы [Philpot 2004; Trilling 1976; Rahn 1993; Matthews, Prothro 1964], так и и отечественные исследования [Петренко, Митина 1991], в которых образ парламента/партии рассматривается в контексте персонификации представлений о политике [McAllister 2007] в тесной взаимосвязи с формируемым на уровне массового сознания образом депутата, парламентария [Рогач 2020]. В настоящем исследовании мы опираемся на постулаты политико-психологического подхода [Шестопал 2019; Селезнева 2019], позволяющего исследовать как рациональные, так и иррациональные компоненты политического сознания, в частности обусловленность российской политической культуры ценностно-символическими категориями (а также идеальными представлениями о политических институтах и акторах) [Bass 1981; Clifford 2018].

Методологические рамки исследования. Эмпирические данные были собраны осенью 2020 г.: получено 420 формализованных интервью (охвачены семь федеральных округов РФ) и 400 графических тестов (рисунки «идеального парламента» и «идеальной партии»). Массив текстовых данных был обработан методом качественно-количественного ненаправленного контент-анализа, а материалы проективных тестов были изучены с помощью политико-психологического содержательно-символического анализа. Выбор исследовательских техник сбора информации был определен исследовательской моделью, опирающейся на политико-психологический подход, согласно которому компонентами политического образа выступают когнитивные, эмоциональные и динамические структуры. Специфичным для образов парламента и политической партии является дополнительное рассмотрение их роли согласно критериям самостоятельности, независимости, значимости для граждан и властной системы. Соотношение характеристик образа, согласно структурным компонентам, определяет его конгруэнтность на рациональном и неосознаваемом уровнях восприятия.

Под когнитивными составляющими образа идеального парламента/партии мы понимаем систему конкретных знаний респондента об этих политических институтах (категории, символы, значения, суждения, логические интерпретации). С учетом исследовательской цели, связанной с изучением образа идеального парламента/партии, нами были выделены категории и характеристики, с помощью которых респондент описывал современный парламент/партию и их соотношение с категориями и характеристиками желаемого (полное или частичное совпадение либо отсутствие взаимосвязи). Эмоциональные состав- 
ляющие - это оценочные реакции респондента, выраженные в позитивации или негативации образа (не всегда связанных с рациональными суждениями). Например, низкая оценка эффективности работы парламента, не подкрепленная осведомленностью респондента о тематике рассматриваемых в последнее время законопроектов, процедурных аспектах его деятельности, регламентах, роли политических партий в законотворческом процессе и т.п. Эмоциональная составляющая связана в большей мере с уверенностью респондента, чем с рационализацией и анализом. Динамические составляющие представлены соотношением рациональных и неосознаваемых пластов сознания, позволяющих респонденту управлять своими действиями. В результате социальной перцепции индивид обрабатывает информацию и принимает решение о политическом действии или бездействии.

Результаты исследования. Когнитивный профиль восприятия. Данный профиль представлен в ответах на вопросы формализованного интервью (испытуемым предлагалось выбрать ответы из числа предложенных на карточках). Представления российских граждан о реальном парламенте и партиях формально структурированы. Респонденты считают, что парламент как орган представительства интересов народа необходим российской политической системе и является наиболее важным институтом после президента. Граждане имеют представление о структуре парламента, в большей степени - о роли нижней палаты в законотворческом процессе, слабо информированы о деятельности парламентских партий. Важными аспектами образа реального парламента, связанными с ожиданиями будущих преобразований, являются эффективность, самостоятельность, открытость.

Примерно половина опрошенных считают результаты работы парламента недостаточно эффективными, не отражающими реальный запрос социальных групп и не удовлетворяющими их интересам (64\%), в связи с чем образ идеального парламента в большей мере связан с концептами эффективности; реальной и необходимой деятельности, оправдания ожиданий, исполнения обещаний, связанных с улучшением социально-экономической ситуации; диалога с народом; открытости; прозрачности; честности; отчетности.

Примерно треть опрошенных считают, что парламент не является самостоятельным органом и зависит от влияния исполнительной власти, особенно на федеральном уровне, в связи с чем образ идеального парламента отражает ожидания усиления значимости; большей самостоятельности, силы и влияния; конкуренции политических партий; включения в повестку парламентских партий обсуждения интересов меньшинства (гендерного, этнического, конфессионального). Эти результаты коррелируют с данными, свидетельствующими, что значительная часть респондентов считают политические партии и их лидеров слабыми.

Большинство российских граждан артикулируют социально-экономическую проблематику развития российского государства и общества и интересуются внутриполитической повесткой. На фоне этого наиболее узнаваемой для них является партия «Единая Россия», в отношении которой были высказаны амбивалентные мнения: часть граждан считают ее наиболее влиятельной, эффективной, служащей интересам народа, в то время как другая часть (либерально настроенная) приписывает этой партии все сложности внутриполитического развития, считает необходимым смену руководства и состава, а также полное обновление идеологической повестки. Непарламентские партии оценивались респондентами гораздо реже и в нейтральном ключе: «они не влияют на политическую повестку», «они не конкурентные», «слабо структурированные», «не имеют широкой поддержки и признания», «их лидеры мало- 
известны». При этом около половины респондентов (47\%) считают, что для идеальной системы власти в России достаточно существования одной-двух партий, которые должны аккумулировать интересы большинства с учетом ожиданий меньшинства, т.е. быть максимально массовыми. Респонденты не считают маленькие партии способными представлять интересы меньшинства и успешно конкурировать с крупными партиями и ожидают прекращения их существования в ближайшем будущем.

Таким образом, в отношении слабо узнаваемых и мало популярных партий мнения разных социальных групп российских граждан схожи, а в отношении парламентских (а следовательно, и наиболее мощных) партий мнения расходятся. И это зависит от многих социально-демографических, локально-территориальных и иных факторов. Так, можно выделить группу тех, кто поддерживает наиболее массовую в настоящее время партию власти, уверен в ее перспективах и эффективности. Вторая группа, значительно меньшая, ориентирована на партии системной оппозиции. Третья группа представлена гражданами, которые имеют амбивалентные представления и которым сложно придерживаться устойчивой позиции.

Эмоциональный профиль восприятия. Исследование эмоционального профиля восприятия парламента/партии осуществлено с помощью содержательно-символического анализа графического материала. Структуру парламента респонденты изображали, используя в т.ч. категории «депутат» и «партия», ввиду чего логично описывать образы парламента и партий во взаимосвязи. Полученные рисунки были сгруппированы следующим образом.

Группа «Парламент» включает два блока. Блок А. «Схема» - рисунки, изображающие структуру парламента и взаимосвязь его частей, а также варианты взаимодействия парламентариев с народом (примерно 2/3 общего числа рисунков). Блок Б. «Абстракция» - рисунки, изображающие предметы, имеющие интерпретационное значение и не связанные напрямую с понятием «парламент» (примерно 1/3 общего числа рисунков).

Группа «Партия» включает четыре блока. Блок А. «Люди»- центральной фигурой-символом является человек (депутат, представитель народа). Блок Б. «Структуры» - центральной фигурой является блок-схема, которая визуально описывает отношения между членами партии, их взаимодействия, а также основной функционал (цели, задачи или результаты деятельности). Особенность этой группы рисунков - отсутствие объема и глубины, слабая детализация, плоскость изображения, взаимосвязи между элементами показаны с помощью слов-конкретизаций. Блок В. «Процедуры» - центральной фигурой является человек или люди, которые показаны в действии (участвуют в заседаниях, обсуждениях, принимают граждан в общественных приемных и т.п.). Блок Г. «Символы-абстракции» - центральной фигурой является не человек, а предметы, ассоциированные респондентом с деятельностью политических партий и отражающие эмоциональные связи. Эти символы подтверждают некоторые политико-культурные шаблоны восприятия, диагностируемые и с помощью вербальных данных: «власть, лидеры, депутаты далеки от народа и его чаяний»; «власть обещает улучшение качества жизни, но на деле сохраняется социально-экономическое неравенство»; «руководители партий, как и рядовые депутаты, не являются сильными лидерами»; «власть и лидеры несменяемы» и т.п. Эмоциональный ракурс этих рисунков негативный, респонденты оценивают положение дел как нехорошее, но при этом не видят перспективы улучшения ситуации.

Рекомендации по конструированию конвенционального образа будущего. Образы идеального парламента и идеальной партии размыты. Это связано с пока еще 
низким политическим активизмом (акции протеста носят точечный, всплесковый характер), особенно в легитимных формах, требующих волевых и интеллектуальных усилий, позитивной консолидации общества и групп, временных и трудозатрат, артикуляции своей гражданской позиции с конкретными решениями, проектами, программами, конструктивной критики, рационализации политического дискурса. Следовательно, в рамках государственной информационной политики необходимо прилагать усилия с целью конструирования позитивных образов, опирающихся на сложившиеся у каждого поколения российских граждан лоялистские политические представления и ценности.

\section{Список литературы}

Воропаева М.А. 2020. Виртуализация образа парламентского института как фактор улучшения восприятия Государственной думы Российской Федерации. - Гуманитарные науки. Вестник Финансового университета. № 5. С. 110-115.

Габдрахманова Г.Р. 2014. Институт законодательной власти в массовом политическом сознании российского общества. - Власть. № 6. С. 73-76.

Кирдяшкин И.В. 2020. Культура как когнитивный фактор политической социализации. - Вестник Томского государственного университета. Философия. Социология. Политология. № 53. С. 213-220.

Моисеева И.В. 2018. Содержательные уровни образа российского парламента: нормативный, реальный и идеальный. - Политика развития, государство и мировой порядок: материалы VIII Всероссийского конгресса политологов (под общ. ред. О.В. Гаман-Голутвиной, Л.В. Сморгунова, Л.Н. Тимофеевой). М.: Аспект Пресс.

Петренко В.Ф., Митина О.В. 1991. Семантическое пространство политических партий. - Психологический журнал. № 6. С. 55-77.

Рогач Н.Н. 2020. Образ идеального депутата государственной думы в массовом сознании российских граждан. - Политическое представительство и публичная власть: трансформационные вызовы и перспективы: материалы ежегодной всероссийской научной конференции с международным участием РАПН (под ред. О.В. Гаман-Голутвиной, Л.В. Сморгунова, Л.Н. Тимофеевой). М.: Изд-во МПГУ.

Селезнева А.В. 2019. Парламентская культура российских граждан: ценностные основания и образно-символическое содержание. - Парламентаризм: региональное измерение (под ред. А.И. Щербинина, А.В. Подрезова, В.Г. Скочиловой). Томск: ИД Томского государственного университета. С. 187191.

Шестопал Е.Б. 2019. Власть и лидеры в восприятии российских граждан. М.: Весь Мир. 656 с.

Щербинин А.И. 2019. Парламент как театр: фрейм и образ. - Парламентаризм: региональное измерение: материалы IV Международной конференции, посвященной 25-летию Законодательной думы Томской области. Томск. С. 243-253.

Bass B.M. 1981. Bass \& Stogdill's Handbook of Leadership: Theory, Research, and Managerial. N.Y.: Free Press. 856 p.

Clifford S. 2018. Reassessing the Structure of Presidential Character. - Electoral Studies. Vol. 54. P. 240-247.

Matthews D.R., Prothro J.W. 1964. Southern Images of Political Parties: An Analysis of White and Negro Attitudes. - The Journal of Politics. Vol. 26. Is. 1. P. 82-111.

McAllister I. 2007. The Personalization of Politics. - Oxford Handbook of Political Behavior (ed. by R.J. Dalton, H.-D. Klingemann). N.Y.: Oxford University Press. P. 571-591. 
Philpot T.S. 2004. A Party of a Different Color? Race, Campaign Communication, and Party Politics. - Political Behavior. Vol. 26. Is. 3. P. 249-270.

Rahn W.M. 1993. The Role of Partisan Stereotypes in Information Processing about Political Candidates. - American Journal of Political Science. Vol. 37. No. 2. P. 472-496.

Trilling R.J. 1976. Party Image and Electoral Behavior. - American Politics Quarterly. Vol. 3. No. 3. P. 284-314.

USMANOVA Zaira Romanovna, Cand.Sci. (Pol.Sci.), Associate Professor of the Department of Political Science, Faculty of Social Sciences and Mass Communications, Financial University under the Government of the Russian Federation (49 Leningradsky Ave, GSP-3, Moscow, Russia, 1259930; ZRUsmanova@fa.ru)

\title{
IMAGES OF IDEAL PARLIAMENT AND POLITICAL PARTY IN THE CONSCIOUSNESS OF RUSSIAN CITIZENS: RESULTS OF POLITICAL AND PSYCHOLOGICAL RESEARCH
}

\begin{abstract}
The article presents the results of a study of the ideal images of parliament and a political party. Based on the political and psychological approach, the following results were obtained. In the minds of the respondents, parliament represents itself by the sum of formal symbols; its image demonstrates cognitive simplicity. The author reveals a high degree of emotional coloring of the image, which reflects largely the personal experiences of the respondents, their desire to improve their socio-economic position than to model possible transformations in the political sphere under conditions of uncertainty. Citizens have a vague idea of party activity, distinguish between the images of the ideal and the acting parties, and single out parliamentary parties among the most recognizable ones.
\end{abstract}

Keywords: ideal parliament, ideal party, State Duma, Federation Council, deputy, government confidence, image of future 